Journal for ImmunoTherapy of Cancer

\title{
Tumor-associated carbohydrates and immunomodulatory lectins as targets for cancer immunotherapy
}

Natalia Rodrigues Mantuano, Marina Natoli (D) , Alfred Zippelius (i) ,

Heinz Läubli

To cite: Rodrigues Mantuano N, Natoli M, Zippelius A, et al. Tumor-associated carbohydrates and immunomodulatory lectins as targets for cancer immunotherapy. Journal for ImmunoTherapy of Cancer 2020;8:e001222. doi:10.1136/ jitc-2020-001222

NRM and MN contributed equally.

Accepted 28 August 2020
Check for updates

(c) Author(s) (or their employer(s)) 2020. Re-use permitted under CC BY-NC. No commercial re-use. See rights and permissions. Published by BMJ.

Department of Biomedicine, Universitätsspital Basel, Basel, Switzerland

Correspondence to Professor Heinz Läubli; heinz.laeubli@unibas.ch

\section{ABSTRACT}

During oncogenesis, tumor cells present specific carbohydrate chains that are new targets for cancer immunotherapy. Whereas these tumor-associated carbohydrates (TACA) can be targeted with antibodies and vaccination approaches, TACA including sialic acidcontaining glycans are able to inhibit anticancer immune responses by engagement of immune receptors on leukocytes. A family of immune-modulating receptors are sialic acid-binding Siglec receptors that have been recently described to inhibit antitumor activity mediated by myeloid cells, natural killer cells and T cells. Other TACA-binding receptors including selectins have been linked to cancer progression. Recent studies have shown that glycan-lectin interactions can be targeted to improve cancer immunotherapy. For example, interactions between the immune checkpoint $\mathrm{T}$ cell immunoglobulin and mucindomain containing- 3 and the lectin galectin- 9 are targeted in clinical trials. In addition, an antibody against the lectin Siglec- 15 is being tested in an early clinical trial. In this review, we summarize the previous and current efforts to target TACA and to inhibit inhibitory immune receptors binding to TACA including the Siglec-sialoglycan axis.

\section{INTRODUCTION}

Recentadvancements in the stimulation of the immune microenvironment and anticancer immune responses with immune checkpoint inhibitors (ICI) has improved the outcome of treatments for patients and has led to impressive long-term remissions in some patients with advanced disease. ${ }^{1-5}$ However, primary and acquired resistance significantly diminish the success of ICI and only a minority of patients benefit from currently available cancer immunotherapies. ${ }^{6} 7$ Thus, new strategies are urgently needed in order to induce long-term remissions with cancer immunotherapy in many more of our patients.

Carbohydrates belong to the major biomolecules of living organisms. Carbohydrates can be attached to proteins (glycoproteins), lipids and exist as chains of carbohydrates (glycosaminoglycans). Glycans-carbohydratecontaining macromolecules-are ubiquitous in biological systems and are essential for numerous biological functions..$^{8-10}$ Cell surfaces and extracellular proteins are significantly glycosylated. In addition, glycosaminoglycans can be found in the extracellular matrix. Glycans are used as storage for energy (glycogen), are structurally important (see later for the stability of programmed cell death protein 1 (PD-1)) and can mediate signals. Whereas proteins undergo substantial post-translational modifications, in particular N-glycosylation and O-glycosylation, ${ }^{8-10}$ intracellular modification of tyrosine with O-GlcNAc serves for intracellular signaling. ${ }^{11}$ Changes of glycosylation have a significant impact on cancer biology and cancer progression. ${ }^{12-15}$ Of note, altered glycan structures represent antigenic targets for cancer immunotherapy. In this review, we summarize how cancer-associated changes in glycosylation can be used to improve cancer immunotherapy.

\section{CANCER-SPECIFIC CHANGES IN GLYCOSYLATION}

Altered glycosylation is a common feature of tumor cells and leads to the formation of tumor-associated carbohydrates (TACA) (figure 1). Three common changes are often associated with cancer: a) increased expression of truncated or incomplete glycans, b) increased branching of N-glycans and c) augmented or changed presence of sialic acid-containing glycans. ${ }^{15}$ Tumor-cellsurface glycans are known to promote cancer progression by affecting tumor growth, cell invasiveness and negatively regulate immune responses. $^{15-17}$ Changes of glycosylation observed in cancer depend on the expression and changes of enzymes involved in glycan biosynthesis and glycan-modifying enzymes including transferases and glycosidases as well as transporter for saccharides and precursors. $^{121418}$ Expression of these glycanmodifying proteins are altered in cancer due 


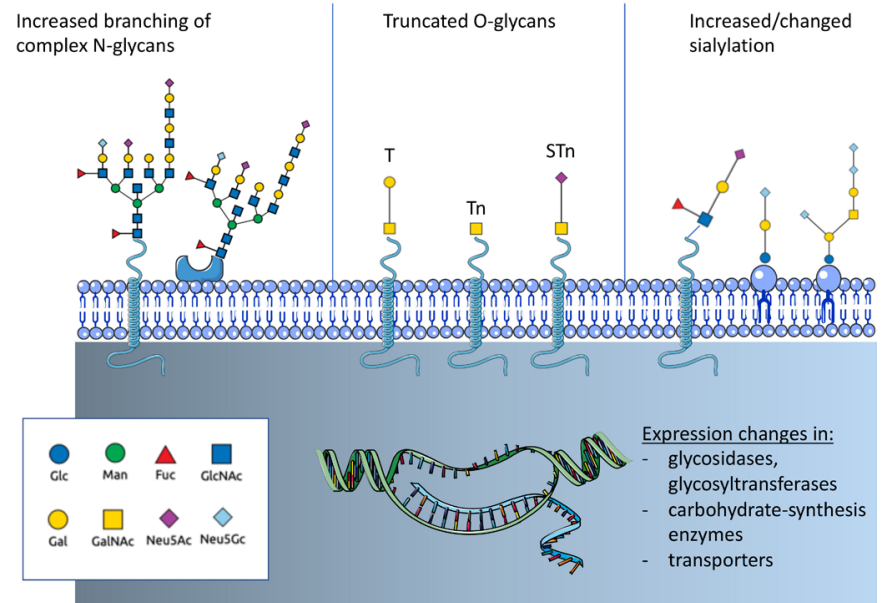

Figure 1 Overview on cancer-associated glycosylation. Three main changes can be found in cancer that are regulated by genetic or epigenetic alterations in genes of glycan-modifying enzymes or enzymes involved in carbohydrate biosynthesis. $\mathrm{N}$-glycans show often an increased branching due to increased MGAT5 expression. Another often observed change is the truncation of O-glycans and the exposure of new tumor-associated carbohydrates (TACA) including the T antigen, Tn antigen and the sialylTn antigen (STn). In addition, changes of sialylation of both glycoproteins and glycolipids can be observed. Increased sialylation (hypersialylation) is often observed. The introduction of the non-human sialic acid Neu5Gc can also be observed. Fuc, fucose; GlcNAc, N-acetyl-glucosamine; Gal, galactose; GalNAc, N-acetyl-galactosamine; Glc, glucose; Man, mannose; N-acetyl-neuraminic acid; Neu5Gc, $\mathrm{N}$-glycosyl-neuraminic acid.

to genetic and epigenetic alterations and differ between cancer types.

\section{Changes in sialylation}

Cancer-associated glycans often exhibit an increased amount of sialic acid. Augmented sialylation of tumor cells has been correlated with a metastatic phenotype and poor prognosis in patients with cancer. ${ }^{19} 20$ Sialic acids are predominantly found at the non-reducing end of $N$-linked and $O$-linked glycans attached to proteins or glycolipids. ${ }^{21}$ Hypersialylation facilitates interactions with sialic acid binding receptors such as selectins and Siglecs with consequences for cancer progression. Moreover, the incorporation of the non-human sialic acid N-glycolyl-neuraminic acid (Neu5Gc) into glycans and the interaction with circulating anti-Neu5Gc antibodies influences cancer progression. ${ }^{22-26}$ Neu5Gc is biosynthesized from $\mathrm{N}$-acetyl-neuraminic acid (Neu5Ac) via the enzyme CMP-Neu5Ac hydroxylase (CMAH), which is not present in humans. ${ }^{27}$ However, various studies have found an increased presence of Neu5Gc-containing glycans in cancer, which could be associated with uptake of meat from Neu5Gc producing mammals. ${ }^{28} 29$

\section{Truncation of 0-glycoproteins}

O-glycans are ubiquituously found on cells and are particularly secreted into the extracellular matrix or into the lumen of internal organs. For example, mucins, highly O-glycosylated proteins such as CA19-9, ${ }^{30}$ can serve as a biomarker for some cancer types. One of the most common cancer-associated changes in glycosylation is the truncation of O-linked carbohydrate chains (figure 1). ${ }^{31}$ Usually, a GalNAc sugar residue is attached to a serine or threonine of the glycoprotein (GalNAco1-O-Ser/ Thr, Tn antigen) and usually elongated by the T-synthase (core $1 \beta 3$-galactosyltransferase) in the Golgi apparatus that attaches a galactose residue to $\mathrm{Tn}$ antigen. The resulting glycan is called $\mathrm{T}$ antigen (sometimes also called the Thomsen-Friedenreich (TF) antigen). The T-synthase requires a chaperone for the correct folding and enzymatic activity. ${ }^{31}$ The chaperone was termed Core $1 \quad \beta 3$-galactosyltransferase Specific Molecular Chaperone (COSMC). ${ }^{32}$ The $\mathrm{X}$ linked COSMC gene is mutated in various cancer types leading to the presence of Tn antigen or its sialylated form, the sialyl-Tn (STn) antigen. $^{31}$ Interestingly, truncated O-glycosylation is shown to have an immunomodulatory effect. Tn antigen binds to macrophage galactose-type lectin on dendritic cells and macrophages that inhibits the migration of immature antigen-presenting cells (APCs) and increases M2-like tumor associated macrophages. ${ }^{33-35}$

Truncated O-glycans represent epitopes which may selectively target cancer cells. Various cancer tissues have been analyzed for the expression for the T, Tn and STn antigen. ${ }^{36-38}$ The human-mucin 1 (MUC1) is overexpressed in many adenocarcinomas, presenting high levels of truncated glycans as STn-MUC1, Tn-MUC1 and T-MUC-1. Yet, these antigens are rarely expressed in normal tissue compared with cancer tissue. ${ }^{39-44}$ Further studies are needed to determine the specificity of the expression patterns if we consider to target these epitopes with antibodies and chimeric antigen receptors (CARs).

\section{Altered branching of $\mathbf{N}$-glycoproteins}

Increased branching of N-glycans, mediated by $\beta 1,6-\mathrm{N}-$ acetylglucosaminyltransferase V (MGAT5, figure 1), ${ }^{12} 15$ can influence cell adhesion, migration and metastasis of tumor cells. ${ }^{45}$ Upregulation of MGAT5 has also been shown to directly influence cytokine signaling and tumor progression ${ }^{47}$ while the knockdown of Mgat5 led to activation of $\mathrm{CD} 4^{+} \mathrm{T}$ cells and macrophages in breast cancer. ${ }^{48}$ Altered N-glycosylation of immune cells could also affect the antitumor immune response. Increased branching of $\mathrm{N}$-glycans can directly inhibit $\mathrm{T}$ cell activation by increasing $\mathrm{T}$ cell receptor (TCR) clustering. ${ }^{49} 50$ This effect was attributed to interaction with galectin-3. ${ }^{49}$ On the other side, TCR signaling also directly influences enzymes modulating N-glycosylation. ${ }^{51}$

\section{Alterations in glycolipids}

Gangliosides are sialylated glycan-containing lipids of the cell membrane show also often changes on cancer cells. The gangliosides GM3, GM2, CD3 and GD2 are present in normal tissue but are often overexpressed in different cancers including lung cancer, melanoma and neurogenic 
tumors such as neuroblastoma. ${ }^{52-55}$ Glycolipids can significantly influence cell signaling by mediating the formation of lipid rafts. ${ }^{56}$ Tumor-associated gangliosides have been investigated for their immunosupressive properties and role in cancer progression. Furthermore, the plasma concentration of gangliosides is often elevated,${ }^{57}$ making them potential therapeutic targets and diagnostic tools. GM3 contains sialic acid-residues and several studies have shown that GM3 containing the non-human sialic acid Neu5Gc (Neu5Gc-GM3) is relatively specific for different types of cancer. ${ }^{29}$

\section{Cancer-associated changes in glycosylation and immune phenotypes}

The association of specific glycan changes with the immune state of a cancer is currently being studied. Immune phenotypes such as $\mathrm{T}$ cell excluded tumors were associated recently with galectin-1 expression and interactions with glycan-ligands. ${ }^{58}$ The Cancer Genome Atlas has been used to study the expression of different glycanmodifying enzymes, for example, for sialic acid-modifying enzymes ${ }^{99}$ However, further systematic studies including also lectin stainings are needed on tissue sections to correlate immune phenotypes with.

\section{MODALITIES TO TARGET TUMOR-ASSOCIATED GLYCANS ADCC and CDC}

Antibody-dependent cellular cytotoxicity (ADCC) or complement-dependent cytotoxicity (CDC) is triggered by the interaction between antibody-bound target cellsfor example, infected or tumor cells-and effector immune cells or complement factors, respectively. Several glycan-targeted monoclonal antibodies (mAbs), which are in clinical use or development, are known to elicit ADCC and/or CDC (figure 2). Among these, dinutuximab, which targets ganglioside GD2 on melanoma, and neuroblastoma (table 1) ${ }^{60-62}$ is approved for the treatment of high-risk neuroblastoma pediatric patients. ${ }^{63}$ Similarly, KW871, a chimeric mAb which targets the ganglioside GD3, exhibited antitumor activity in combination with with IFN $_{\alpha} 2 \mathrm{~b}$ in vitro. ${ }^{64}$ In patients with metastatic melanoma, the combination of KW871 with interferon was shown to be well tolerated, although not highly efficacious. ${ }^{65}$ An anti-idiotype antibody was generated to elucidate an immune response against Neu5Gc-GM3. ${ }^{66}$ Early trials have shown interesting activity in patients with nonsmall cell lung cancer (NSCLC). ${ }^{66} 67$ Trials testing the efficacy of this antibody called racotumomab in a larger population are currently recruiting (eg, NCT01460472).

Since the 1990s, several other mAbs have been designed that target Lewis antigens (Le), expressed by a broad range of tumor cells, and that are able to elicit ADCC and/or CDC in preclinical and clinical studies. Examples of such mAbs are BR96 ${ }^{68}$ targeting Le ${ }^{\mathrm{y}}$; hu3S193, ${ }^{69}$ a humanized anti-Le ${ }^{y} \mathrm{mAb}$ which showed low toxicity in an early clinical trial, ${ }^{70}$ but insufficient efficacy in a subsequent phase II trial. ${ }^{71}$

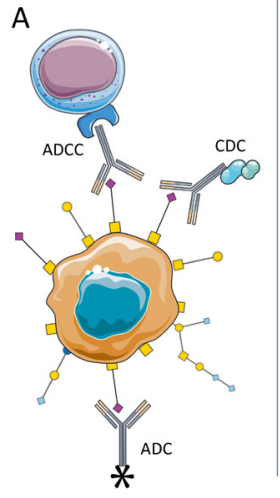

B
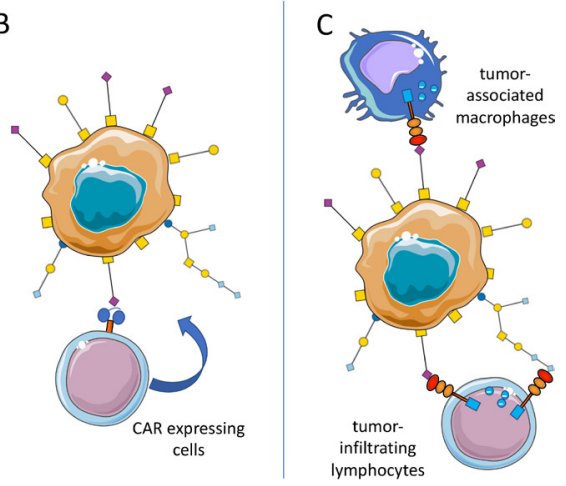

Figure 2 Overview on targeting approaches for cancer-associated glycosylation. (A) Tumor-associated carbohydrates (TACA) can serve as tumor-specific antigen and be approached with antibody-dependent cellular cytotoxicity (ADCC)-inducing or complement-dependent cytotoxicity (CDC)-inducing antibodies or with antibodies carrying a payload (chemotherapy or even enzyme). (B) Chimeric antigen receptor (CAR) expressing immune cells could be redirected towards TACA-presenting tumors. Similarly, bispecific antibodies could be used to direct immune cells to TACA-expressing tumors (not shown). (C) TACA such as sialoglycans can engage immune receptors including inhibitory Siglec receptors on T cells and myeloid cells and improve anticancer immunity directly. ADC, antibody-drug conjugates.

As for targeting of tumor-associated MUC1 (TA-MUC1) expressed on several malignancies including ovarian, breast and cervical cancers, ${ }^{72}$ the mAb PankoMab-GEX (gatipotuzumab) has shown therapeutic efficacy, particularly in heavily pretreated patients with ovarian cancer. ${ }^{7374}$ Yet, the subsequent phase II trial did not to show any outcome advantage. ${ }^{75}$ Another high-affinity mAb named 5E5 targets the aberrant Tn glycoform of mucin MUC1 and has been shown to lyse breast cancer cells via both ADCC and CDC. ${ }^{76}$

Glycosylation is also under investigation to be used as tool for the enhancement of ADCC and CDC immune response mechanisms. Indeed, manipulation of specific residues of the Fc N-glycan has been shown to modulate antibody-dependent effector functions via modification of the Fc binding affinity to $\mathrm{Fc}$ receptors expressed on different immune cells. Particularly, core fucosylation and sialylation of Fc regions results in decreased ADCC, while $\mathrm{N}$-glycans with low or no sialic acid are better suited to trigger ADCC. These approaches are reviewed by Wang and Ravetch ${ }^{77}$ and Mastrangeli and colleagues. ${ }^{78}$

\section{Antibody-drug conjugates}

Antibody-drug conjugates (ADCs) unify the properties of cytotoxic chemotherapy and mAbs, in an effort to selectively target and lyse cancer cells. Similarly, antiglycandirected antibodies can be exploited to deliver selected anticancer payloads specifically to tumor cells (figure 2). First attempts used the previously mentioned anti- $\mathrm{Le}^{\mathrm{y}}$ BR96 mAb, conjugated to doxorubicin and docetaxel. This ADC was tested in phase II trials for advanced NSCLC 
Table 1 Previous and ongoing clinical trials targeting tumor-associated glycans or lectins

\begin{tabular}{|c|c|c|c|c|c|}
\hline Target & Drug candidate & Modality & Phase & Cancer type & Citation/Trial ID \\
\hline NeuGcGM3 & Racotumomab & Vaccine & II/III & NSCLC & $\begin{array}{l}\left(\begin{array}{l}6667 \\
\text { NCT01460472 }\end{array}\right. \\
\text { N }\end{array}$ \\
\hline MUC1 & $\begin{array}{l}\text { PankoMab-GEX } \\
\text { (Gatipotuzumab) }\end{array}$ & $\mathrm{mAb}$ & $\mathrm{I} / \mathrm{II}$ & $\begin{array}{l}\text { Advanced carcinoma; recurrent ovarian } \\
\text { carcinoma }\end{array}$ & $\left({ }^{7475}\right)$ \\
\hline Lewis-Y antigen & BMS-1 82248-1 & ADC & II & Metastatic breast cancer & $(80)$ \\
\hline CD22/CD19 & DT2219 & $\mathrm{BsAb}$ & I & Refractory B-cell malignancies & $\left({ }^{89}\right)$ \\
\hline TAG72 & CART72 & CAR T & 1 & Advanced colorectal cancer & $\left({ }^{96}\right)$ \\
\hline Lewis-Y antigen & $\mathrm{Le}^{\mathrm{y}}-\mathrm{CAR} \mathrm{T}$ & CAR T & I & AML & $\left({ }^{102}\right)$ \\
\hline IL15-GD2 & GINAKIT & CAR-NKT & I & Pediatric neuroblastoma & NCT03294954 \\
\hline STn & Theratope & ADC & III & Metastatic breast adenocarcinoma & $\left({ }^{115} 116\right)$ \\
\hline Siglec-15 & NC318 & $\mathrm{mAb}$ & $\mathrm{I} / \mathrm{II}$ & Advanced or metastatic solid tumors & NCT03665285 \\
\hline
\end{tabular}

ADC, antibody-drug conjugates; AML, acute myeloid leukemia; mAb, monoclonal antibody; MUC1, mucin 1; NSCLC, non-small cell lung cancer; PD-1, programmed cell death protein 1.

(table 1$)^{79}$ and for metastatic breast cancer. ${ }^{80}$ Although initial results were encouraging, the $\mathrm{mAb}$ was later discontinued, likely due to low efficacy. More recent attempts at exploiting tumor glycan expression for drug delivery include work by Sedlik et al, who used a Tn-directed mAb (Chi-Tn) to deliver cytotoxic drugs; they showed promising antitumor activity of the chiTn ADC in vitro and in vitro, when this was conjugated to saporin or auristatin $\mathrm{F}^{81}$ These effects were particularly dependent on high Tn expression in tumor cells. ${ }^{81}$ Similarly, Prendergast et al developed murine mAbs able to target tumor cells expressing STn with high avidity and further exploited a subset of these mAbs as ADCs by conjugating them to monomethyl auristatin E (MMAE). ${ }^{82}$ These ADCs showed high efficacy in vitro, in the presence of STn-expressing cancer cell lines, as well as tumor inhibition in multiple in vivo model, including breast and colorectal cancer. ${ }^{82}$ Furthermore, humanized anti-STn antibodies conjugated to MMAE have been shown to determine in vitro cytotoxicity specific to STn-expressing ovarian cancer cell lines as well as efficacy in tumor control in in vivo models for ovarian cancers, including in patient-derived xenografts. ${ }^{83}$ These humanized aSTn-ADCs were further shown to present a low toxicity profile as they did not cross-react to any tissue of human origin. Most recently, the murine mAb FG129 and corresponding chimeric human variant CH129, were developed to target sialyldi-Le ${ }^{\mathrm{a}}$-containing glycoproteins and shown to bind to a range of cancer tissues including colorectal, pancreatic, gastric and ovarian tumors. ${ }^{84}$ Conjugation of $\mathrm{CH} 129$ to either MMAE or maytansinoid (DM1 and DM4) resulted in cell death in vitro, as well as in vivo tumor control. ${ }^{84}$

\section{Bispecific antibodies}

Bispecific antibodies (bsAbs) are molecules designed to recognize two distinct antigens or epitopes and have been recently emerging as potential key actors in cancer immunotherapy. In terms of tumor-associated glycans, research on bsAbs has so far focused on targeting GD2 ganglioside and MUC1 combined (table 1) ${ }^{85-88}$ Recent developments involve also targeting of glycan-binding lectins on tumor cells. bsAbs designed to target lectins including Siglecs are currently under investigation, for example, bsAb against CD22/CD19 on B cells-currently in a phase III trial, targeting B cell malignancies ${ }^{89}$ or bsAb bridging CD33 on AML cells to CD3 on T cells ${ }^{90} 91$ or to CD16 on natural killer (NK) cells. ${ }^{92}$

\section{Redirection of immune cells}

CARs can redirect immune cells to tumor cells or the tumor microenvironment by targeting tumor-specific antigens. ${ }^{93}{ }^{94}$ However, design of CARs directed at solid cancers presents several challenges, due to the immunosuppressive mechanisms within the TME and the difficulty in finding antigens that are solely cancer-specific. ${ }^{94}$

Targeting CARs to glycans may be advantageous due to the specificity of aberrant glycosylation on tumor cells. Several attempts at designing glycan-targeted CARs have been made and are currently being tested in preclinical and clinical studies (table 1). Tumor-associated glycoprotein 
72 (TAG72) antigen is the truncated sialyl-Tn found on many O-glycoproteins and overexpressed by various types of cancer cells, including lung, colorectal and ovarian cancer cells. TAG72-direceted CAR T cells were shown to be effective in vitro on gastrointestinal cancer cell lines. ${ }^{95}$ A much more recent clinical trial using anti-TAG72 CAR $\mathrm{T}$ cells in advanced colorectal cancer patients failed to show effective clinical responses; this was potentially due to the murine origin of the $\mathrm{scFv}$ or to lack of co-stimulation $^{96}$; the second-generation TAG72-targeted CAR was shown to effectively target ovarian cancer cell lines and patient-derived primary ovarian cancer cells in vitro, as well as to reduce tumor growth and improve survival in mice, with sequential intraperitoneal administrations. ${ }^{97}$ Attempts at designing MUC1-targeted CARs relied on two main antibodies, SM3 and HMFG2. ${ }^{98}$ More recent Tn-MUC1-targeting CARs have been developed from the 5E5 mAb and shown to present cancer-specificity and weak reactivity against healthy tissues, as well as to effectively target and kill cancer cells in pancreatic and leukemia xenograft models. ${ }^{99}$ A successful target for CAR $\mathrm{T}$ cell therapy is the TACA Le ${ }^{\mathrm{y}}$. A second generation fully humanized CAR construct targeting Le $^{\mathrm{y}}$ was shown to be effectively transduced in PBMC-derived $\mathrm{T}$ cells and to lyse $\mathrm{Le}^{\mathrm{y}}$ positive tumorcell lines in vitro. ${ }^{100}$ Similarly, in vivo, adoptive transfer of $\mathrm{Le}^{\mathrm{y}}$ - targeted CAR $\mathrm{T}$ cells resulted in tumor homing and subsequently inhibiting growth of myeloma and ovarian cancer xenografts. ${ }^{100} 101$ The same CAR $T$ cells were tested in four patients with relapsed AML, presenting $\mathrm{Le}^{\mathrm{y}}$ positive blasts, in a phase I clinical trial. ${ }^{102}$ An ongoing Phase I clinical trial is now testing the safety and tolerability of using these CAR T cells in patients with advanced solid tumors presenting Le $^{y}$ surface expression (NCT03851146).

In high-risk neuroblastoma patients with EpsteinBarr virus (EBV)-associated malignancies, infusion of EBV-specific and GD2 CAR-transduced T cells showed persistence of these cells and tumor necrosis in some patients, ${ }^{103}$ with three patients showing complete responses and two long-term remission (up to 48 months) in a long-term follow-up study. ${ }^{104}$ Combination of GD2targeted CARs with PD-1 blockade is also under investigation, with studies showing that, in vitro, anti-PD-1 can rescue GD2 CARs from activation-induced cell death, ${ }^{105} \mathrm{a}$ phenomenon also observed in vivo in patients with metastatic melanoma treated with GD2-specific CAR T cells in a phase I clinical trial. ${ }^{105}$ In another phase I clinical trial, combination of a third-generation GD2-targeted CAR with lymphodepletion and PD-1 blockade resulted in improved in vivo expansion of the CAR T cells, which were safely tolerated, but modest clinical responses. ${ }^{106} \mathrm{~A}$ recent proof-of-concept study showed that incorporating IL-12 or IL-18 within a GD2-targeting CAR resulted in enhanced effector functions and increased monocyte recruitment in vitro. ${ }^{107}$ Another phase I clinical trial testing IL15-GD2 CAR NKT cells in pediatric patients with neuroblastoma is currently ongoing (NCT03294954). More recent attempts at using immune cells other than $\mathrm{T}$ cells for GD-2 targeted CARs include work by Mitwasi $e t a l$, who used a 'universal' CAR platform (UniCAR) to target NK cell line NK-92 to GD2 expressing cells. ${ }^{108}$ UniCARs present an 'on/off system', which allows for controlling the activity of CAR expressing cells, depending on the presence of a target module, that is, an antibody-based cell-binding domain specific to GD2. ${ }^{108}$

\section{Vaccination}

Several vaccines have been developed based on different glycans Tn-MUC1, ${ }^{109}$ MUC16, ${ }^{110}$ GD2, ${ }^{111} 112$ GM2 ${ }^{112}$ and Neu5Gc-GM3, ${ }^{113}{ }^{114}$ but most vaccines had major issues relating to the poor immunogenicity of glycans and glycopeptides. Glycan-based vaccine research is therefore currently focused on addressing these problems and enhancing immunogenicity of these immunotherapies. A strategy to increase immunogenicity is conjugation to carrier proteins; one such example is Theratope, an STn-based vaccine conjugated to carrier protein keyhole limpet hemocyanin. Though initial evaluations of Theratope in patients with metastatic adenocarcinomas produced encouraging results, ${ }^{115}$ including increased antibody titres and prolonged survival, this vaccine was later shelved after failing to meet its primary endpoints in a phase III clinical trial. ${ }^{116}$ Other strategies to enhance glycan immunogenicity include designing polyvalent vaccines which contain multiple glycan structures, such as Globo-H, STn, Tn, TF and Le $\mathrm{e}^{\mathrm{y} 117}$ or using peptide mimetics of TACAs, such as for SLex, SLea, SLe ${ }^{y}$ or Tn, to prevent enzymatic degradation and improve antitumor efficacy. ${ }^{118} 119$

Glycan modifications can also be used to target shared or neo-antigens to APCs including dendritic cells. ${ }^{120}$ Dendritic cells express lectins binding to glycan epitopes. For example, dendritic cells express the lectins Dendritic Cell-Specific Intercellular adhesion molecule-3-Grabbing Non-integrin (DC-SIGN) and Langerin that can be targeted with fucosylated glycans of Lewis-type oligosaccharides. ${ }^{121}$ In another work, Siglec-1 on macrophages was targeted to induce an immune response to a lipid antigen and robustly activate NK T cells. ${ }^{122}$

\section{TARGETING GLYCAN-RECEPTOR INTERACTIONS TO IMPROVE CANCER IMMUNOTHERAPY Siglec-sialoglycan interactions}

Recent evidence also suggests that cancer-associated glycosylation can directly influence anticancer immunity by binding to glycan binding receptors, which are also called lectins. ${ }^{12-14} 123124$ Hypersialylated glycan structures have been identified in various types of cancer. ${ }^{1422} 24$ The high density of sialoglycans on some tumor cells can engage inhibitory sialoglycan-binding receptors called Siglecs. ${ }^{25125126}$ Siglecs belong to the family of immunoglobulin (I)-type lectins. ${ }^{125} 127128$ Siglecs are single-pass transmembrane proteins and bind sialoglycans through their carbohydrate-binding domain (table 2). ${ }^{125} 127128$ In humans, there are 14 functionally active Siglec receptors 
Table 2 Summary of human Siglec receptors, their expression on the surface of different cells, their intracellular signaling and their binding to sialic acid-containing glycan ligands

\begin{tabular}{|c|c|c|c|}
\hline Siglec & Expression & Function & Binding specificity \\
\hline Siglec-3, CD33 & $\begin{array}{l}\text { Myeloid cells (including } \\
\text { neutrophils, monoytes and } \\
\text { progenitors) }\end{array}$ & Inhibitory Siglec (ITIM, ITIM-like) & $\alpha 2,6>\alpha 2,3$ \\
\hline $\begin{array}{l}\text { Siglec- } 4 \text {, myelin-associated } \\
\text { glycoprotein }\end{array}$ & Myelin producing cells & $\begin{array}{l}\text { No intracellular ITIM or ITIM-like motifs, } \\
\text { important for }\end{array}$ & $\alpha 2,3>\alpha 2,6$ \\
\hline Siglec-5 & $\begin{array}{l}\text { Monocytes, macrophages, } \\
\text { neutrophils, activated T cells }\end{array}$ & $\begin{array}{l}\text { Inhibitory Siglec (ITIM, ITIM-like), paired } \\
\text { receptor with Siglec-14 }\end{array}$ & $\alpha 2,3$ \\
\hline Siglec-6 & $\begin{array}{l}\text { Trophoblast, chronic } \\
\text { lymphocytic leukemia cells }\end{array}$ & Inhibitory Siglec (ITIM, ITIM-like) & $\alpha 2,6$ \\
\hline Siglec-9 & $\begin{array}{l}\text { Myeloid cells, NK cells, } \\
\text { intratumoral T cells, } \\
\text { dendritic cells }\end{array}$ & Inhibitory Siglec (ITIM, ITIM-like) & $\begin{array}{l}\alpha 2,3=\alpha 2,6 \text {, broadly binding, } \\
\text { also binding to some protein } \\
\text { ligand }\end{array}$ \\
\hline Siglec-10 & B cells, $T$ cells & Inhibitory Siglec (ITIM, ITIM-like) & $\alpha 2,3=\alpha 2,6$ \\
\hline Siglec-11 & Macrophages, microglia & $\begin{array}{l}\text { Inhibitory Siglec (ITIM, ITIM-like), paired } \\
\text { receptor wit }\end{array}$ & $\alpha 2,8$ \\
\hline Siglec-XII & Epithelial cells, cancer cells & $\begin{array}{l}\text { No binding to sialic acid-containing } \\
\text { ligands (mutation of essential arginine in } \\
\text { carbohydrate-recognition }\end{array}$ & $\begin{array}{l}\text { No binding to sialic acid } \\
\text { ligands }\end{array}$ \\
\hline Siglec-14 & $\begin{array}{l}\text { Monocytes, macrophages, } \\
\text { neutrophils }\end{array}$ & $\begin{array}{l}\text { Activating Siglec, positively charged } \\
\text { amino acid mediates binding to DAP12, } \\
\text { paired receptor with Siglec-5 }\end{array}$ & $\begin{array}{l}\alpha 2,3 \\
\text { similar binding as its paired } \\
\text { receptor Siglec- } 5\end{array}$ \\
\hline
\end{tabular}

ITIM, immunoreceptor tyrosine-based inhibitory motif.

that can be divided into two groups. On one side, there are evolutionary conserved Siglec receptors including Siglec-1, Siglec-2 (CD22), Siglec-4 and Siglec-15. On the other side, CD33-related Siglecs have rapidly evolved also within mammalian species. ${ }^{22}{ }^{129}$ Siglec-3 (CD33), Siglec-5, Siglec-6, Siglec-7, Siglec-8, Siglec-9, Siglec-10, Siglec-11 and Siglec-14 belong to the CD33-related Siglecs and there are for most of them no direct orthologs, for example, in mice and humans. ${ }^{128}$ Most Siglec receptor have intracellular domains containing immunoreceptor tyrosine-based inhibitory motifs (ITIM) or ITIM-like motifs. Engagement of these inhibitory receptors lead to a phosphorylation of Src homology region 2 domain-containing phosphatase (SHP)-1 and SHP-2, which inhibit cell activation. ${ }^{22} 128$ Most Siglec receptors are expressed on immune cells and engagement inhibits immune cell activation. Diversification of CD33-related Siglecs is probably due to interactions with pathogens exploiting inhibitory Siglec receptors by covering themselves with sialoglycans. ${ }^{130}$ Some pathogens as the group B streptococci have even developed proteins to engage inhibitory Siglecs on myeloid cells and thereby evade immune-mediated killing. ${ }^{131}$

The role of Siglec receptors as new targetable immune checkpoints has been recently reviewed in depth. ${ }^{23} 25125126132$ Expression of inhibitory Siglec receptors on innate immune cells have been linked to inhibition of anticancer immunity. ${ }^{12}{ }^{13125}$ Siglec-7 is expressed on the majority of NK cells and Siglec-9 can be found on some subpopulations of NK cells. ${ }^{128} 133$ Upregulation of sialoglycans on cancer cells can inhibit NK cell-mediated tumor cell killing by engaging Siglec-7 and in some instances also Siglec-9. ${ }^{133} 134$ Siglec-9 expression has been shown to skew macrophage polarization to a protumorigenic phenotype and increased programmed death ligand 1 (PD-L1) expression on macrophages. ${ }^{135}$ Siglec-9 engagement was shown to be dependent in this set of experiments on STnmodified mucins. ${ }^{135}$ Other experiments in mice showed that myeloid polarization is affected by inhibitory Siglec 
receptors including Siglec-E, the functional paralog of Siglec-9 in mice. ${ }^{136}$ Recent evidence demonstrated that Siglec-10 on macrophages can act as a "don't eat me" signal to inhibit phagocytosis. ${ }^{137}$

Of note, the expression of Siglecs on adaptive immune cells including $\mathrm{CD} 8^{+} \mathrm{T}$ cells are inhibiting effective anticancer immunity as shown by us and others. Siglec-9 is upregulated on tumor-infiltrating $\mathrm{T}$ cells in various cancers including NSCLC, colorectal cancer, epithelial ovarian cancer and melanoma. ${ }^{138139}$ Tumor growth was significantly enhanced in a transgenic mouse model of overexpression of Siglec-9 on T cells. ${ }^{138}$ Siglec-9 was expressed mainly on tumor-specific $\mathrm{T}$ cells shown by a reduced TCR repertoire in tumor infiltrating $\mathrm{CD}^{+} \mathrm{T}$ cells. ${ }^{139}$ Interestingly, Siglec-9 positive $\mathrm{CD} 8^{+} \mathrm{T}$ cells represent a less dysfunctional intratumoral $\mathrm{T}$ cell subtype and Siglec-9 blockade could reactivate these T cells. ${ }^{138}$ The conserved Siglec-15 was identified as inhibitor of $\mathrm{T}$ cell activation on APCs. ${ }^{140}$

Approaches to target sialoglycan-Siglec interactions could involve both blocking the Siglec receptor, for example, with an antibody. Siglec-15 was targeted with an antibody in preclinical mouse models ${ }^{140}$ and is already in an early clinical trial for advanced solid tumors (NCT03665285). On the other side, the ligand could be targeted enzymatically with sialidases or with small molecules interfering with sialoglycan biosynthesis. ${ }^{141} 142$ The use of sialic acid analogs in vivo by intratumoral injection could block the sialoglycan biosynthesis and led to a strong activation intratumoral $\mathrm{T}$ cells, ${ }^{141}$ however the systemic application of these analogs would be quite toxic. Bacterial sialidase was tested in a system linked to the HER2-targeting antibody trastuzumab and NK cell-mediated tumor cell killing was tested in vitro. ${ }^{142}$ Recently, HER2-targeted bacterial sialidase was tested in vivo in syngeneic mice and showed efficacy. ${ }^{143}$ Currently, a humanized version of this tumor-targeted sialidase is in clinical development and the toxicity profile needs to be further tested.

\section{Targeting selectins}

Selectins belong to the class of C-type lectins and bind mainly to sialoglycans. ${ }^{144}$ The three selectins, E-selectin, P-selectin and L-selectin (CD62E, CD62P and CD62L) bind to different sialylated ligands, often containing sialyl$\mathrm{Le}^{\mathrm{x}}$ in a relatively selective manner and mediate interactions between platelets expressing P-selectin, leukocytes expressing L-selectin and endothelial cells expressing P-selectin and E-selectin. ${ }^{145}{ }^{146}$ Expression of L-selectin on $\mathrm{T}$ cells can enhance cancer immunotherapy in mouse models. ${ }^{147}$ The P-selectin ligand carrying protein P-selectin glycoprotein ligand (PSGL)-1 was identified to be involved in $\mathrm{T}$ cell exhaustion, ${ }^{148}$ and was also shown to inhibit in anticancer immunity through its proteinprotein interaction with the immune checkpoint VISTA, an inhibitory receptor expressed on T cells. ${ }^{149}$ However, these studies have not directly implicated interactions of the carbohydrate-modification of PSGL-1 to their effect on anticancer immunity and these effects are probably P-selectin independent. As sialoglycan-selectin interactions play an important role in leukocyte trafficking and mediation of immune responses, it is likely that sialogylcan-selectin interactions could influence anticancer immunity. Indeed, recent experiments demonstrate that modification of CAR T cells to bind to selectins can improve anticancer efficacy. ${ }^{150} 151$ However, further studies are needed to determine the role of selectins in anticancer immunity and how these interactions can be exploited for cancer immunotherapy.

\section{Galectin-mediated interactions}

Galectins are a class of carbohydrates-binding proteins capable of recognizing $\beta$-galactose via their carbohydratebinding domain. ${ }^{152-154}$ Aberrant expression of galectins is frequent in cancer cells as well as in stromal cells and is associated with tumor progression. ${ }^{153}$ Importantly, galectins are involved in mediating interactions between tumor cells and innate and adaptive immune cells; upregulation of galectins by tumor cells is regarded as a mechanism of tumor immune escape,${ }^{152-154}$ with some galectins being ligands for immune checkpoint receptors. For example, galectin-3 binds to cytotoxic T lymphocyte antigen 4 (CTLA-4) and lymphocyte activaiton gene 3 (LAG-3), ${ }^{155} 156$ whereas galectin-9 binds to T cell immunoglobulin and mucin-domain containing-3 (TIM-3)..$^{157}$

Galectin-1 is found upregulated in many different tumors and has been shown to antagonistically bind to the TCR, thus disrupting TCR signaling, and to determine T cell apoptosis, via redistribution of CD3 and CD45 clusters as well as CD7 and CD43 clusters. ${ }^{158-160}$ Early studies suggested that silencing expression of galectin-1 in tumor cells may be a strategy to enhance T-cell-mediated antitumor responses. ${ }^{161}$ Recently, a novel Gal-1-targeting DNA aptamer (AP-74 M-545) was developed and shown to suppress lung carcinoma growth in immunocompetent models. This was accompanied by an increase in $\mathrm{CD}^{+}$and $\mathrm{CD} 8^{+} \mathrm{T}$ cells, possibly by blocking the binding of galectin-1 to CD $45 .{ }^{162}$ Nambial and colleagues showed that galectin-1 also prevents $\mathrm{T}$ cell migration into the tumor by upregulating PD-L1 and galectin-9 expression on endothelial cells. Blockade of galectin-1 resulted in increased $\mathrm{T}$ cell infiltration in multiple head and neck cancer mouse models as well as enhanced response to PD-1 blockade and radiotherapy combinations. ${ }^{58}$ Similarly, knockdown of galectin-1 in a mouse model of pancreatic ductal adenocarcinoma increased survival and enhanced $\mathrm{T}$ cell infiltration. ${ }^{163}$ In NSCLC, high expression of galectin-3 in the tumor microenvironment is associated with poor outcome ${ }^{164}$ and targeting of this galectin with an antagonist has been shown to inhibit lung adenocarcinoma growth and enhance response to PD-L1 blockade in vivo. ${ }^{165}$ Moreover, LAG-3 and interactions with galaectin-3 are also under investigation as a target for cancer immunotherapy in preclinical and clinical studies. ${ }^{156} 166-168$ 
Similarly, galectin-9/TIM-3 interactions are a recent target of immunotherapeutic intervention ${ }^{169}$ due to its suppressive properties of the antitumor immune response. ${ }^{168-170}$

\section{Interactions with other lectins}

C-type lectins are known to be involved in immunity, cell proliferation, tumor invasion and metastasis making them potential targets for cancer research such as selectins, DC-SIGN, Mincle, Dectin 1 and NKG2D. ${ }^{171} 172$ The C-type lectins are a superfamily of proteins that recognize a broad repertoire of ligands which the main feature is the C-type lectin-like domain. Cells of the adaptive and innate immune system commonly express c-type lectins including all myeloid cells, lymphocytes and dendritic cells. ${ }^{172-174}$ The lectin DC-SIGN can be recognized by glycosylated intercellular adhesion molecule 2 (ICAM-2) forming a DC-SIGN-ICAM-2 complex. This complex allows the maturation of dendritic cells that induces a specific cytotoxic $\mathrm{T}$ lymphocyte-modulated immune response promoting antitumor activity. ${ }^{171}$ Consisted with this, the DC-SIGN-Mac2 complex also inhibited the maturation of dendritic cells in colorectal carcinoma. ${ }^{175}$ DC-SIGN also has other ligands such as carcinoembryonic antigen and Le. ${ }^{176}$ A recent work has found that sialylation of antibodies could dampen autoimmune disease with potential consequences. ${ }^{177}$ Dectin-1 expressed on dendritic cells and macrophages is critical to the NK-mediated killing of tumor cells that expressed N-glycans in high levels. ${ }^{178}$ Furthermore, NK62DG is expressed on the surface of dendritic cells and its soluble ligands are very high in cancer leading to immunosuppression and poor prognosis in patients with cancer. ${ }^{179} 180 \mathrm{In}$ addition, the engagement of macrophage-inducible C-type lectin (Mincle) has been associated with immunosuppression and tumor progression. ${ }^{181}$

\section{Impact of glycosylation on immune checkpoints}

Glycosylation can mediate stability of different receptors and can influence cancer progression. ${ }^{12}$ Immune checkpoints are also glycosylated and targeting glycosylation of PD-1 can improve anticancer immunity. ${ }^{182}$ PD-1 in T cells is N-glycosylated and its N-glycosylation is critical for the stability on the cell surface. ${ }^{182}$ In addition, a glycosylation site on PD-1 was critical for interaction with PD-L1. ${ }^{182}$ On the other side, glycosylation of PD-L1 is also critical for its stability and targeting PD-L1 glycosylation could be used to improve anticancer immunotherapy. ${ }^{183} 184$ Moreover, the detection of PD-L1 in human cancers is dependent on glycosylation and could influence the predictive power of PD-L1 staining and the use of PD-(L) 1 blocking antibodies in patients. ${ }^{185}$ Also, CTLA-4-mediated interactions are glycan-dependent and binding as well as stability could be influenced. ${ }^{186} 187$

\section{Glycosylation and signaling pathways involved in resistance to immune checkpoint inhibitors}

Several intracellular signaling pathways have been associated with resistance to ICI therapy including the activation of WNT/ $\beta$-catenin signaling, MYC signaling and loss of phosphatase and tensin homolog (PTEN). ${ }^{188}$ Activation of the WNT/ $\beta$-catenin signaling pathway has been shown to increase the production of immunosuppressive cytokines, ${ }^{189}$ prevention of the recruitment of BATF ${ }^{+}$dendritic cells ${ }^{190} 191$ and a shift towards an increase in regulatory $\mathrm{T}$ cells in the tumor. ${ }^{192}$ $\mathrm{WNT} / \beta$-catenin signaling is also regulating glycosylation by promoting the expression of the enzyme DPAGT1 and thereby enhancing increased N-glycosylation. ${ }^{193}$ Increased N-glycosylation could further enhance immune evasion by providing ligands for immunomodulatory receptors such as Siglecs. MYC can influence the expression of PD-L1 and thereby influence the immune microenvironment in tumors. ${ }^{194}$ In addition, MYC signaling can directly mediate immune cell exhaustion in NSCLC. ${ }^{195}$ MYC is directly regulated by O-GlcNAcylation. ${ }^{196}$ O-GlcNAcylation was needed for proliferation and MYC stability. ${ }^{196}$

\section{CONCLUSION AND OUTLOOK}

Recent discoveries and progress have revealed that tumorassociated carbohydrates are a interesting new target for cancer immunotherapy interventions. Many therapeutic opportunities are ready to be explored and targeting of TACA has just started as new field within cancer immunotherapy. Further studies are needed to determine patient populations that could benefit from such interventions. Whereas for proteins, the epidemiology and expression patterns are often well studied, the epidemiology of glycan expression will be important in order to determine the frequency of specific expression in cancer types and also during therapeutic interventions. In addition, glycan-mediated interactions with immunomodulatory lectins on leukocytes including Siglecs can directly affect anticancer immunity. Siglec-sialoglycan interactions have been described as potential new immune checkpoint. A first successful application in an early clinical trials with the Siglec-15 blocking agent (NC318) is promising. Besides the role as antigen and immunomodulatory factor, glycans can directly influence the stability and turnover of immune receptors including immune checkpoints.

We are confident that the field of glyco-immunology will enable us to improve cancer immunotherapy and help many of our patients by further studying mechanisms involved in glycan-mediated immune suppression and developing new approaches to target cancer-associated glycans.

Contributors NRM, MN, AZ and HL have written the manuscript. All authors have approved the final version for publication.

Funding This work was supported by funding from the Goldschmidt-Jacobson Foundation, the Swiss National Science Foundation (SNSF grant \#3 10 030-1 $84720)$, the Schoenemakers-Müller Foundation and the Cancer League of Basel (KlbB).

Competing interests HL received travel grants and consultant fees from Bristol Myers Squibb (BMS) and Merck, Sharp and Dohme (MSD). HL received research support from BMS and Palleon Pharmaceuticals. 
Patient consent for publication Not required.

Provenance and peer review Not commissioned; externally peer reviewed.

Open access This is an open access article distributed in accordance with the Creative Commons Attribution Non Commercial (CC BY-NC 4.0) license, which permits others to distribute, remix, adapt, build upon this work non-commercially, and license their derivative works on different terms, provided the original work is properly cited, appropriate credit is given, any changes made indicated, and the use is non-commercial. See http://creativecommons.org/licenses/by-nc/4.0/.

\section{ORCID iDs}

Marina Natoli http://orcid.org/0000-0002-0270-0225

Alfred Zippelius http://orcid.org/0000-0003-1933-8178

Heinz Läubli http://orcid.org/0000-0002-8910-5620

\section{REFERENCES}

1 Vasan N, Baselga J, Hyman DM. A view on drug resistance in cancer. Nature 2019;575:299-309.

2 Hanahan D, Weinberg RA. Hallmarks of cancer: the next generation Cell 2011;144:646-74.

3 Larkin J, Chiarion-Sileni V, Gonzalez R, et al. Five-Year survival with combined nivolumab and ipilimumab in advanced melanoma. $N$ Engl J Med Overseas Ed 2019;381:1535-46.

4 Chen DS, Mellman I. Elements of cancer immunity and the cancerimmune set point. Nature 2017;541:321-30.

5 Wei SC, Duffy CR, Allison JP. Fundamental mechanisms of immune checkpoint blockade therapy. Cancer Discov 2018;8:1069-86.

6 Sharma P, Hu-Lieskovan S, Wargo JA, et al. Primary, adaptive, and acquired resistance to cancer immunotherapy. Cell 2017;168:707-23.

7 Haslam A, Prasad V. Estimation of the percentage of US patients with cancer who are eligible for and respond to checkpoint inhibitor immunotherapy drugs. JAMA Netw Open 2019;2:e192535.

8 Varki A, Gagneux P. Biological Functions of Glycans. In: Varki A, Cummings RD, Esko JD, et al, eds. Essentials of glycobiology. Harbor, NY: Cold Spring, 2015: 77-88.

9 Ohtsubo K, Marth JD. Glycosylation in cellular mechanisms of health and disease. Cell 2006;126:855-67.

10 Varki A. Biological roles of glycans. Glycobiology 2017;27:3-49.

11 Zachara N, Akimoto Y, Hart GW. The O-GlcNAc Modification. In: Varki A, Cummings RD, Esko JD, et al, eds. Essentials of glycobiology. Harbor, NY: Cold Spring, 2015: 239-51.

12 Mereiter S, Balmaña M, Campos D, et al. Glycosylation in the era of Cancer-Targeted therapy: where are we heading? Cancer Cell 2019;36:6-16.

13 Rodríguez E, Schetters STT, van Kooyk Y. The tumour glycocode as a novel immune checkpoint for immunotherapy. Nat Rev Immunol 2018;18:204-11.

14 Boligan KF, Mesa C, Fernandez LE, et al. Cancer intelligence acquired $(\mathrm{ClA})$ : tumor glycosylation and sialylation codes dismantling antitumor defense. Cell Mol Life Sci 2015;72:1231-48.

15 Varki A, Kannagi R, Toole B, et al. Glycosylation Changes in Cancer In: Varki A, Cummings RD, Esko JD, et al, eds. Essentials of glycobiology. Harbor, NY: Cold Spring, 2015: 597-609.

16 Häuselmann I, Borsig L. Altered tumor-cell glycosylation promotes metastasis. Front Oncol 2014;4:28.

17 Vasconcelos-dos-Santos A, Oliveira IA, Lucena MC, et al. Biosynthetic machinery involved in aberrant glycosylation promising targets for developing of drugs against cancer. Front Oncol 2015:5:138.

18 Pinho SS, Reis CA. Glycosylation in cancer: mechanisms and clinical implications. Nat Rev Cancer 2015;15:540-55.

19 Amado M, Carneiro F, Seixas M, et al. Dimeric sialyl-Le(x) expression in gastric carcinoma correlates with venous invasion and poor outcome. Gastroenterology 1998;114:462-70.

20 Baldus SE, Zirbes TK, Mönig SP, et al. Histopathological subtypes and prognosis of gastric cancer are correlated with the expression of mucin-associated sialylated antigens: Sialosyl-Lewis(a), SialosylLewis(x) and sialosyl-Tn. Tumour Biol 1998;19:445-53.

21 Schauer R. Achievements and challenges of sialic acid research. Glycoconj J 2000;17:485-99.

22 Läubli H, Varki A. Sialic acid-binding immunoglobulin-like lectins (siglecs) detect self-associated molecular patterns to regulate immune responses. Cell. Mol. Life Sci. 2020;77:593-605.

23 Adams OJ, Stanczak MA, von Gunten S, et al. Targeting sialic acid-Siglec interactions to reverse immune suppression in cancer. Glycobiology 2018;28:640-7.
24 Pearce OMT, Läubli H. Sialic acids in cancer biology and immunity. Glycobiology 2016;26:111-28.

25 van de Wall S, Santegoets KCM, van Houtum EJH, et al. Sialoglycans and siglecs can shape the tumor immune microenvironment. Trends Immunol 2020;41:274-85.

26 Samraj AN, Pearce OMT, Läubli H, et al. A red meat-derived glycan promotes inflammation and cancer progression. Proc Natl Acad Sci U S A 2015;112:542-7.

27 Dhar C, Sasmal A, Varki A. From "Serum Sickness" to "Xenosialitis": Past, Present, and Future Significance of the Non-human Sialic Acid Neu5Gc. Front Immunol 2019;10:807.

28 Hedlund M, Padler-Karavani V, Varki NM, et al. Evidence for a human-specific mechanism for diet and antibody-mediated inflammation in carcinoma progression. Proc Natl Acad Sci U S A 2008;105:18936-41.

29 Samraj AN, Läubli H, Varki N, et al. Involvement of a non-human sialic acid in human cancer. Front Oncol 2014:4:33.

30 Hollingsworth MA, Swanson BJ. Mucins in cancer: protection and control of the cell surface. Nat Rev Cancer 2004;4:45-60.

31 Ju T, Aryal RP, Kudelka MR, et al. The Cosmc connection to the Tn antigen in cancer. CBM 2014;14:63-81.

32 Ju T, Cummings RD. A unique molecular chaperone Cosmc required for activity of the mammalian core 13 -galactosyltransferase. Proc Natl Acad Sci U S A 2002;99:16613-8.

33 Allavena P, Chieppa M, Bianchi G, et al. Engagement of the mannose receptor by tumoral mucins activates an immune suppressive phenotype in human tumor-associated macrophages. Clin Dev Immunol 2010;2010:1-10.

34 Dusoswa SA, Verhoeff J, Abels E, et al. Glioblastomas exploit truncated $\mathrm{O}$ - linked glycans for local and distant immune modulation via the macrophage galactose-type lectin. Proc Nat Acad Sci U S A 2020;117:3693-703

35 van Vliet SJ, Bay S, Vuist IM, et al. Mgl signaling augments TLR2mediated responses for enhanced IL-10 and TNF- $\alpha$ secretion. $J$ Leukoc Biol 2013;94:315-23.

36 Munkley J. The role of sialyl-Tn in cancer. Int J Mol Sci 2016;17:275.

$37 \mathrm{Fu} \mathrm{C}$, Zhao $\mathrm{H}$, Wang $\mathrm{Y}$, et al. Tumor-Associated antigens: Tn antigen, sTn antigen, and T antigen. HLA 2016;88:275-86.

38 Cazet $A$, Julien S, Bobowski M, et al. Tumour-Associated carbohydrate antigens in breast cancer. Breast Cancer Res 2010;12:204.

39 Thor A, Ohuchi N, Szpak CA, et al. Distribution of oncofetal antigen tumor-associated glycoprotein-72 defined by monoclonal antibody B72.3. Cancer Res 1986;46:3118-24.

40 Sewell R, Bäckström M, Dalziel M, et al. The ST6GalNAc-I sialyltransferase localizes throughout the Golgi and is responsible for the synthesis of the tumor-associated sialyl-Tn O-glycan in human breast cancer. J Biol Chem 2006;281:3586-94.

41 Marcos NT, Bennett EP, Gomes J, et al. St6Galnac-I controls expression of sialyl-Tn antigen in gastrointestinal tissues. Front Biosci 2011;3:1443-55.

42 Stanick D, Schuss A, Mishriki Y, et al. Reactivity of the monoclonal antibody B72.3 with fetal antigen: correlation with expression of TAG-72 in human carcinomas. Cancer Invest 1988;6:279-87.

43 Cao Y, Stosiek P, Springer GF, et al. Thomsen-Friedenreich-related carbohydrate antigens in normal adult human tissues: a systematic and comparative study. Histochem Cell Biol 1996;106:197-207.

44 Remmers N, Anderson JM, Linde EM, et al. Aberrant expression of mucin core proteins and O-linked glycans associated with progression of pancreatic cancer. Clin Cancer Res 2013;19:1981-93.

45 Granovsky M, Fata J, Pawling J, et al. Suppression of tumor growth and metastasis in Mgat5-deficient mice. Nat Med 2000;6:306-12.

46 Hou S, Hang Q, Isaji T, et al. Importance of membrane-proximal $N$ glycosylation on integrin $\beta 1$ in its activation and complex formation. Faseb J 2016;30:4120-31.

47 Partridge EA, Le Roy C, Di Guglielmo GM, et al. Regulation of cytokine receptors by Golgi N-glycan processing and endocytosis. Science 2004;306:120-4.

48 Li D, Li Y, Wu X, et al. Knockdown of Mgat5 inhibits breast cancer cell growth with activation of $\mathrm{CD}^{+} \mathrm{T}$ cells and macrophages. $J$ Immunol 2008;180:3158-65.

49 Demetriou M, Granovsky M, Quaggin S, et al. Negative regulation of T-cell activation and autoimmunity by Mgat5 N-glycosylation. Nature 2001;409:733-9.

50 Grigorian A, Lee S-U, Tian W, et al. Control of T cell-mediated autoimmunity by metabolite flux to $\mathrm{N}$-glycan biosynthesis. J Biol Chem 2007;282:20027-35.

51 Chen H-L, Li CF, Grigorian A, et al. T cell receptor signaling coregulates multiple Golgi genes to enhance $N$-glycan branching. $J$ Biol Chem 2009;284:32454-61. 
52 Hakomori S. Tumor malignancy defined by aberrant glycosylation and sphingo(glyco)lipid metabolism. Cancer Res 1996;56:5309-18.

53 Shinoura N, Dohi T, Kondo T, et al. Ganglioside composition and its relation to clinical data in brain tumors. Neurosurgery 1992;31:541-9.

54 Hayashi N, Chiba H, Kuronuma K, et al. Detection of N-glycolyated gangliosides in non-small-cell lung cancer using GMR8 monoclonal antibody. Cancer Sci 2013;104:43-7.

55 Popa I, Pons A, Mariller C, et al. Purification and structural characterization of de-N-acetylated form of GD3 ganglioside present in human melanoma tumors. Glycobiology 2007;17:367-73.

56 Hakomori S. Bifunctional role of glycosphingolipids. Modulators for transmembrane signaling and mediators for cellular interactions. $J$ Biol Chem 1990;265:18713-6.

57 Ladisch S, Wu ZL. Detection of a tumour-associated ganglioside in plasma of patients with neuroblastoma. Lancet 1985;1:136-8.

58 Nambiar DK, Aguilera T, Cao H, et al. Galectin-1-driven T cell exclusion in the tumor endothelium promotes immunotherapy resistance. J Clin Invest 2019;129:5553-67.

59 Haas Q, Simillion C, von Gunten S. A cartography of siglecs and sialyltransferases in gynecologic malignancies: is there a road towards a sweet future? Front Oncol 2018;8:68.

60 Modak S, Gerald W, Cheung N-KV. Disialoganglioside GD2 and a novel tumor antigen: potential targets for immunotherapy of desmoplastic small round cell tumor. Med Pediatr Oncol 2002;39:547-51.

61 Mujoo K, Cheresh DA, Yang HM, et al. Disialoganglioside GD2 on human neuroblastoma cells: target antigen for monoclonal antibody-mediated cytolysis and suppression of tumor growth. Cancer Res 1987;47:1098-104.

62 Cheung NK, Saarinen UM, Neely JE, et al. Monoclonal antibodies to a glycolipid antigen on human neuroblastoma cells. Cancer Res 1985;45:2642-9.

63 Keyel ME, Reynolds CP. Spotlight on dinutuximab in the treatment of high-risk neuroblastoma: development and place in therapy. Biologics 2019;13:1-12.

64 Liu Z, Lee FT, Hanai N, et al. Cytokine enhancement of in vitro antibody-dependent cellular cytotoxicity mediated by chimeric antiGD3 monoclonal antibody KM871. Cancer Immun 2002;2:13.

65 Tarhini AA, Moschos SJ, Lin Y, et al. Safety and efficacy of the antiganglioside GD3 antibody ecromeximab (KW2871) combined with high-dose interferon- $\alpha 2 b$ in patients with metastatic melanoma. Melanoma Res 2017;27:342-50.

66 Hernández AM, Toledo D, Martínez D, et al. Characterization of the antibody response against NeuGcGM3 ganglioside elicited in non-small cell lung cancer patients immunized with an anti-idiotype antibody. J Immunol 2008;181:6625-34.

67 Alfonso S, Valdés-Zayas A, Santiesteban ER, et al. A randomized, multicenter, placebo-controlled clinical trial of racotumomab-alum vaccine as switch maintenance therapy in advanced non-small cell lung cancer patients. Clin Cancer Res 2014;20:3660-71.

68 Hellström I, Garrigues HJ, Garrigues U, et al. Highly tumor-reactive, internalizing, mouse monoclonal antibodies to Le(y)-related cell surface antigens. Cancer Res 1990;50:2183-90.

69 Scott AM, Geleick D, Rubira M, et al. Construction, production, and characterization of humanized anti-Lewis $Y$ monoclonal antibody 3 S193 for targeted immunotherapy of solid tumors. Cancer Res 2000;60:3254-61.

70 Scott AM, Tebbutt N, Lee F-T, et al. A phase I biodistribution and pharmacokinetic trial of humanized monoclonal antibody Hu3s193 in patients with advanced epithelial cancers that express the Lewis-Y antigen. Clin Cancer Res 2007;13:3286-92.

71 Smaletz O, Diz MDPE, do Carmo CC, et al. A phase II trial with anti-Lewis-Y monoclonal antibody (hu3S193) for the treatment of platinum resistant/refractory ovarian, fallopian tube and primary peritoneal carcinoma. Gynecol Oncol 2015;138:272-7.

72 Heublein S, Mayr D, Egger M, et al. Immunoreactivity of the fully humanized therapeutic antibody PankoMab-GEXTM is an independent prognostic marker for breast cancer patients. J Exp Clin Cancer Res 2015;34:50.

73 Danielczyk A, Stahn R, Faulstich D, et al. PankoMab: a potent new generation anti-tumour MUC1 antibody. Cancer Immunol Immunother 2006:55:1337-47.

74 Fiedler W, DeDosso S, Cresta S, et al. A phase I study of PankoMab-GEX, a humanised glyco-optimised monoclonal antibody to a novel tumour-specific MUC1 glycopeptide epitope in patients with advanced carcinomas. Eur J Cancer 2016;63:55-63.

75 Ledermann J, Sehouli J, Zurawski B, et al. A double-blind, placebo-controlled, randomized, phase 2 study to evaluate the efficacy and safety of switch maintenance therapy with the antiTA-MUC1 antibody PankoMab-GEX after chemotherapy in patients with recurrent epithelial ovarian carcinoma. Annals of Oncology 2017;28:v626-49.

76 Lavrsen K, Madsen CB, Rasch MG, et al. Aberrantly glycosylated MUC1 is expressed on the surface of breast cancer cells and a target for antibody-dependent cell-mediated cytotoxicity. Glycoconj J 2013;30:227-36.

77 Wang TT, Ravetch JV. Functional diversification of IgGs through Fc glycosylation. J Clin Invest 2019;129:3492-8.

78 Mastrangeli R, Palinsky W, Bierau H. Glycoengineered antibodies: towards the next-generation of immunotherapeutics. Glycobiology 2019;29:199-210.

79 Ross HJ, Hart LL, Swanson PM, et al. A randomized, multicenter study to determine the safety and efficacy of the immunoconjugate SGN-15 plus docetaxel for the treatment of non-small cell lung carcinoma. Lung Cancer 2006;54:69-77.

80 Tolcher AW, Sugarman S, Gelmon KA, et al. Randomized phase II study of BR96-doxorubicin conjugate in patients with metastatic breast cancer. JCO 1999;17:478-84.

81 Sedlik C, Heitzmann A, Viel S, et al. Effective antitumor therapy based on a novel antibody-drug conjugate targeting the $\mathrm{Tn}$ carbohydrate antigen. Oncoimmunology 2016;5:e1171434.

82 Prendergast JM, Galvao da Silva AP, Eavarone DA, et al. Novel anti-Sialyl-Tn monoclonal antibodies and antibody-drug conjugates demonstrate tumor specificity and anti-tumor activity. MAbs 2017:9:615-27.

83 Eavarone DA, Al-Alem L, Lugovskoy A, et al. Humanized anti-SialylTn antibodies for the treatment of ovarian carcinoma. PLoS One 2018:13:e0201314.

84 Tivadar ST, Mclntosh RS, Chua JX, et al. Monoclonal Antibody Targeting Sialyl-di-Lewis ${ }^{\text {a }}$-Containing Internalizing and Noninternalizing Glycoproteins with Cancer Immunotherapy Development Potential. Mol Cancer Ther 2020;19:790-801.

85 Katayose Y, Kudo T, Suzuki M, et al. MUC1-specific targeting immunotherapy with bispecific antibodies: inhibition of xenografted human bile duct carcinoma growth. Cancer Res 1996;56:4205-12.

86 Kodama H, Suzuki M, Katayose Y, et al. Specific and effective targeting cancer immunotherapy with a combination of three bispecific antibodies. Immunol Lett 2002;81:99-106.

87 Li Y, Zhou C, Li J, et al. Single domain based bispecific antibody, Muc1-Bi-1, and its humanized form, Muc1-Bi-2, induce potent cancer cell killing in MUC1 positive tumor cells. PLoS One 2018;13:e0191024.

88 Hoseini SS, Dobrenkov K, Pankov D, et al. Bispecific antibody does not induce T-cell death mediated by chimeric antigen receptor against disialoganglioside GD2. Oncoimmunology 2017;6:e1320625

89 Bachanova V, Frankel AE, Cao Q, et al. Phase I study of a bispecific ligand-directed toxin targeting CD22 and CD19 (DT2219) for refractory B-cell malignancies. Clin Cancer Res 2015;21:1267-72.

90 Friedrich M, Henn A, Raum T, et al. Preclinical characterization of AMG 330, a CD3/CD33-bispecific T-cell-engaging antibody with potential for treatment of acute myelogenous leukemia. Mol Cancer Ther 2014;13:1549-57.

91 Arndt C, von Bonin M, Cartellieri M, et al. Redirection of T cells with a first fully humanized bispecific CD33-CD3 antibody efficiently eliminates AML blasts without harming hematopoietic stem cells. Leukemia 2013;27:964-7.

92 Gleason MK, Ross JA, Warlick ED, et al. CD16xCD33 bispecific killer cell engager (bike) activates NK cells against primary MDS and MDSC CD33+ targets. Blood 2014;123:3016-26.

93 Boyiadzis MM, Dhodapkar MV, Brentjens RJ, et al. Chimeric antigen receptor (CAR) T therapies for the treatment of hematologic malignancies: clinical perspective and significance. J Immunother Cancer 2018;6:137

94 Weber EW, Maus MV, Mackall CL. The emerging landscape of immune cell therapies. Cell 2020;181:46-62.

95 Hombach A, Heuser C, Sircar R, et al. T cell targeting of TAG72+ tumor cells by a chimeric receptor with antibody-like specificity for a carbohydrate epitope. Gastroenterology 1997;113:1163-70.

96 Hege KM, Bergsland EK, Fisher GA, et al. Safety, tumor trafficking and immunogenicity of chimeric antigen receptor (CAR)-T cells specific for TAG-72 in colorectal cancer. J Immunother Cancer 2017;5:22.

97 Murad JP, Kozlowska AK, Lee HJ, et al. Effective Targeting of TAG72 $2^{+}$Peritoneal Ovarian Tumors via Regional Delivery of CAREngineered T Cells. Front Immunol 2018;9:2268.

98 Wilkie S, Picco G, Foster J, et al. Retargeting of human T cells to tumor-associated MUC1: the evolution of a chimeric antigen receptor. J Immunol 2008;180:4901-9.

99 Posey AD, Schwab RD, Boesteanu AC, et al. Engineered CAR $T$ cells targeting the cancer-associated Tn-Glycoform of the 
membrane mucin MUC1 control adenocarcinoma. Immunity 2016;44:1444-54.

100 Westwood JA, Smyth MJ, Teng MWL, et al. Adoptive transfer of $T$ cells modified with a humanized chimeric receptor gene inhibits growth of Lewis-Y-expressing tumors in mice. Proc Natl Acad Sci $U$ $S$ A 2005;102:19051-6.

101 Peinert S, Prince HM, Guru PM, et al. Gene-Modified T cells as immunotherapy for multiple myeloma and acute myeloid leukemia expressing the Lewis Y antigen. Gene Ther 2010;17:678-86.

102 Ritchie DS, Neeson PJ, Khot A, et al. Persistence and efficacy of second generation CAR T cell against the Ley antigen in acute myeloid leukemia. Mol Ther 2013;21:2122-9.

103 Pule MA, Savoldo B, Myers GD, et al. Virus-Specific T cells engineered to coexpress tumor-specific receptors: persistence and antitumor activity in individuals with neuroblastoma. Nat Med 2008;14:1264-70.

104 Louis CU, Savoldo B, Dotti G, et al. Antitumor activity and long-term fate of chimeric antigen receptor-positive $T$ cells in patients with neuroblastoma. Blood 2011;118:6050-6.

105 Gargett T, Yu W, Dotti G, et al. GD2-specific CAR T cells undergo potent activation and deletion following antigen encounter but can be protected from activation-induced cell death by PD-1 blockade. Mol Ther 2016;24:1135-49.

106 Heczey A, Louis CU, Savoldo B, et al. Car T cells administered in combination with Lymphodepletion and PD-1 inhibition to patients with neuroblastoma. Mol Ther 2017;25:2214-24.

107 Zimmermann K, Kuehle J, Dragon AC, et al. Design and Characterization of an "All-in-One" Lentiviral Vector System Combining Constitutive Anti- $\mathrm{G}_{\mathrm{D} 2}$ CAR Expression and Inducible Cytokines. Cancers 2020;12:375.

108 Mitwasi N, Feldmann A, Arndt C, et al. "UniCAR"-modified off-theshelf NK-92 cells for targeting of GD2-expressing tumour cells. Sci Rep 2020;10:2141.

109 O'Boyle KP, Zamore R, Adluri S, et al. Immunization of colorectal cancer patients with modified ovine submaxillary gland mucin and adjuvants induces IgM and IgG antibodies to sialylated Tn. Cancer Res 1992;52:5663-7.

110 Reinartz S, Köhler S, Schlebusch H, et al. Vaccination of patients with advanced ovarian carcinoma with the anti-idiotype ACA125: immunological response and survival (phase Ib/II). Clin Cancer Res 2004:10:1580-7.

111 Ragupathi G, Livingston PO, Hood C, et al. Consistent antibody response against ganglioside GD2 induced in patients with melanoma by a GD2 lactone-keyhole limpet hemocyanin conjugate vaccine plus immunological adjuvant QS-21. Clin Cancer Res 2003;9:5214-20.

112 Chapman PB, Morrisey D, Panageas KS, et al. Vaccination with a bivalent $G(M 2)$ and $G(D 2)$ ganglioside conjugate vaccine: a trial comparing doses of $\mathrm{G}(\mathrm{D} 2)$-keyhole limpet hemocyanin. Clin Cancer Res 2000;6:4658-62.

113 Vázquez AM, Hernández AM, Macías A, et al. Racotumomab: an anti-idiotype vaccine related to $\mathrm{N}$-glycolyl-containing gangliosides preclinical and clinical data. Front Oncol 2012;2:150

114 Carr A, Rodríguez E, Arango MdelC, et al. Immunotherapy of advanced breast cancer with a heterophilic ganglioside (NeuGcGM3) cancer vaccine. J Clin Oncol 2003;21:1015-21.

115 MacLean GD, Reddish MA, Koganty RR, et al. Antibodies against mucin-associated sialyl-Tn epitopes correlate with survival of metastatic adenocarcinoma patients undergoing active specific immunotherapy with synthetic STN vaccine. J Immunother Emphasis Tumor Immunol 1996;19:59-68.

116 Miles D, Roché H, Martin M, et al. Phase III multicenter clinical trial of the sialyl-TN (STn)-keyhole limpet hemocyanin $(\mathrm{KLH})$ vaccine for metastatic breast cancer. Oncologist 2011;16:1092-100.

117 Ragupathi G, Koide F, Livingston PO, et al. Preparation and evaluation of unimolecular pentavalent and hexavalent antigenic constructs targeting prostate and breast cancer: a synthetic route to anticancer vaccine candidates. J Am Chem Soc 2006;128:2715-25

118 Richichi B, Thomas B, Fiore M, et al. A cancer therapeutic vaccine based on clustered Tn-antigen mimetics induces strong antibody-mediated protective immunity. Angew Chem Int Ed Engl 2014:53:11917-20.

119 Kieber-Emmons T, Saha S, Pashov A, et al. Carbohydrate-Mimetic peptides for pan anti-tumor responses. Front Immunol 2014:5:308.

120 Duinkerken S, Li RE, van Haften FJ, et al. Chemically engineered glycan-modified cancer vaccines to mobilize skin dendritic cells. Curr Opin Chem Biol 2019;53:167-72.

121 Porkolab V, Chabrol E, Varga N, et al. Rational-Differential design of highly specific Glycomimetic ligands: targeting DC-SIGN and excluding langerin recognition. ACS Chem Biol 2018;13:600-8.
122 Kawasaki N, Vela JL, Nycholat CM, et al. Targeted delivery of lipid antigen to macrophages via the CD169/sialoadhesin endocytic pathway induces robust invariant natural killer T cell activation. Proc Natl Acad Sci U S A 2013;110:7826-31.

123 Cummings RD, Schnaar RL, Esko JD, et al. Principles of Glycan Recognition. In: Varki A, Cummings RD, Esko JD, et al, eds. Essentials of glycobiology. Harbor, NY: Cold Spring, 2015: 373-85.

124 Fuster MM, Esko JD. The sweet and sour of cancer: glycans as novel therapeutic targets. Nat Rev Cancer 2005;5:526-42.

125 Bärenwaldt A, Läubli H. The sialoglycan-Siglec glyco-immune checkpoint - a target for improving innate and adaptive anti-cancer immunity. Expert Opin Ther Targets 2019;23:839-53.

126 Duan S, Paulson JC. Siglecs as immune cell checkpoints in disease. Annu Rev Immunol 2020;38:365-95.

127 Varki A, Schnaar RL, Crocker PR, et al. I-Type Lectins. In: Varki A, Cummings RD, Esko JD, et al, eds. Essentials of glycobiology. Harbor, NY: Cold Spring, 2015: 453-67.

128 Macauley MS, Crocker PR, Paulson JC. Siglec-mediated regulation of immune cell function in disease. Nat Rev Immunol 2014;14:653-66.

129 Angata T. Possible influences of endogenous and exogenous ligands on the evolution of human siglecs. Front Immunol 2018;9:2885.

130 Chang Y-C, Nizet V. Siglecs at the host-pathogen interface. Adv Exp Med Biol 2020;1204:197-214.

131 Carlin AF, Chang Y-C, Areschoug T, et al. Group B Streptococcus suppression of phagocyte functions by protein-mediated engagement of human Siglec-5. J Exp Med 2009;206:1691-9.

132 Rodrigues E, Macauley MS. Hypersialylation in cancer: modulation of inflammation and therapeutic opportunities. Cancers 2018;10:207.

133 Jandus C, Boligan KF, Chijioke O, et al. Interactions between Siglec-7/9 receptors and ligands influence NK cell-dependent tumor immunosurveillance. J Clin Invest 2014;124:1810-20.

134 Hudak JE, Canham SM, Bertozzi CR. Glycocalyx engineering reveals a Siglec-based mechanism for NK cell immunoevasion. Nat Chem Biol 2014;10:69-75.

135 Beatson R, Tajadura-Ortega V, Achkova D, et al. The mucin MUC1 modulates the tumor immunological microenvironment through engagement of the lectin Siglec-9. Nat Immunol 2016;17:1273-81.

136 Läubli H, Pearce OMT, Schwarz F, et al. Engagement of myelomonocytic siglecs by tumor-associated ligands modulates the innate immune response to cancer. Proc Natl Acad Sci U S A 2014:111:14211-6.

137 Barkal AA, Brewer RE, Markovic M, et al. Cd24 signalling through macrophage Siglec-10 is a target for cancer immunotherapy. Nature 2019;572:392-6.

138 Stanczak MA, Siddiqui SS, Trefny MP, et al. Self-Associated molecular patterns mediate cancer immune evasion by engaging siglecs on T cells. J Clin Invest 2018;128:4912-23.

139 Haas Q, Boligan KF, Jandus C, et al. Siglec-9 Regulates an Effector Memory CD8 ${ }^{+}$T-cell Subset That Congregates in the Melanoma Tumor Microenvironment. Cancer Immunol Res 2019;7:707-18.

140 Wang J, Sun J, Liu LN, et al. Siglec-15 as an immune suppressor and potential target for normalization cancer immunotherapy. Nat Med 2019;25:656-66.

141 Büll C, Boltje TJ, Balneger N, et al. Sialic acid blockade suppresses tumor growth by enhancing T-cell-mediated tumor immunity. Cancer Res 2018;78:3574-88.

142 Xiao H, Woods EC, Vukojicic P, et al. Precision glycocalyx editing as a strategy for cancer immunotherapy. Proc Natl Acad Sci U S A 2016;113:10304-9.

143 Gray MA, Stanczak MA, Mantuano NR, et al. Targeted glycan degradation potentiates the anticancer immune response in vivo. Nat Chem Biol 2020. doi:10.1038/s41589-020-0622-x. [Epub ahead of print: 17 Aug 2020].

144 Cummings RD, McEver RP, Lectins C-T. C-Type Lectins. In: Varki A, Cummings RD, Esko JD, et al, eds. Essentials of glycobiology. Harbor, NY: Cold Spring, 2015: 435-52.

145 McEver RP. Selectins: initiators of leucocyte adhesion and signalling at the vascular wall. Cardiovasc Res 2015;107:331-9.

146 Kansas GS. Selectins and their ligands: current concepts and controversies. Blood 1996;88:3259-87.

147 Watson HA, Durairaj RRP, Ohme J, et al. L-Selectin enhanced T cells improve the efficacy of cancer immunotherapy. Front Immunol 2019;10:1321.

148 Tinoco R, Carrette F, Barraza ML, et al. Psgl-1 is an immune checkpoint regulator that promotes $\mathrm{T}$ cell exhaustion. Immunity 2016;44:1190-203.

149 Johnston RJ, Su LJ, Pinckney J, et al. Vista is an acidic pHselective ligand for PSGL-1. Nature 2019;574:565-70. 
150 Mondal N, Silva M, Castano AP, et al. Glycoengineering of chimeric antigen receptor (CAR) T-cells to enforce E-selectin binding. J Biol Chem 2019;294:18465-74

151 Sackstein R. The first step in adoptive cell immunotherapeutics: assuring cell delivery via glycoengineering. Front Immunol 2018;9:3084.

152 Barondes SH, Castronovo V, Cooper DN, et al. Galectins: a family of animal beta-galactoside-binding lectins. Cell 1994;76:597-8.

153 Liu F-T, Rabinovich GA. Galectins as modulators of tumour progression. Nat Rev Cancer 2005;5:29-41.

154 Cummings RD, Liu FT, Vasta GR. Galectins. In: Varki A, Cummings RD, Esko JD, et al, eds. Essentials of glycobiology. Harbor, NY: Cold Spring, 2015: 469-80.

155 Stillman BN, Hsu DK, Pang M, et al. Galectin-3 and galectin-1 bind distinct cell surface glycoprotein receptors to induce T cell death. $J$ Immunol 2006;176:778-89.

156 Kouo T, Huang L, Pucsek AB, et al. Galectin-3 shapes antitumor immune responses by suppressing CD8+ T cells via LAG-3 and inhibiting expansion of plasmacytoid dendritic cells. Cancer Immunology Research 2015;3:412-23.

157 Zhu C, Anderson AC, Schubart A, et al. The Tim-3 ligand galectin-9 negatively regulates $T$ helper type 1 immunity. Nat Immunol 2005;6:1245-52.

158 Astorgues-Xerri L, Riveiro ME, Tijeras-Raballand A, et al. Unraveling galectin-1 as a novel therapeutic target for cancer. Cancer Treat Rev 2014;40:307-19.

159 Chung CD, Patel VP, Moran M, et al. Galectin-1 induces partial TCR zeta-chain phosphorylation and antagonizes processive TCR signal transduction. J Immunol 2000;165:3722-9.

160 Pace KE, Lee C, Stewart PL, et al. Restricted receptor segregation into membrane microdomains occurs on human T cells during apoptosis induced by galectin-1. J Immunol 1999;163:3801-11.

161 Rubinstein N, Alvarez M, Zwirner NW, et al. Targeted inhibition of galectin-1 gene expression in tumor cells results in heightened T cell-mediated rejection; a potential mechanism of tumor-immune privilege. Cancer Cell 2004;5:241-51.

162 Tsai Y-T, Liang C-H, Yu J-H, et al. A DNA aptamer targeting galectin-1 as a novel immunotherapeutic strategy for lung cancer Mol Ther Nucleic Acids 2019;18:991-8.

163 Orozco CA, Martinez-Bosch N, Guerrero PE, et al. Targeting galectin-1 inhibits pancreatic cancer progression by modulating tumor-stroma crosstalk. Proc Natl Acad Sci U S A 2018;115:E3769-78.

164 Mathieu A, Saal I, Vuckovic A, et al. Nuclear galectin-3 expression is an independent predictive factor of recurrence for adenocarcinoma and squamous cell carcinoma of the lung. Mod Pathol 2005;18:1264-71.

165 Vuong L, Kouverianou E, Rooney CM, et al. An orally active galectin-3 antagonist inhibits lung adenocarcinoma growth and augments response to PD-L1 blockade. Cancer Res 2019;79:1480-92.

166 Nguyen LT, Ohashi PS. Clinical blockade of PD1 and LAG3potential mechanisms of action. Nat Rev Immunol 2015:15:45-56.

167 Andrews LP, Marciscano AE, Drake CG, et al. LAG3 (CD223) as a cancer immunotherapy target. Immunol Rev 2017;276:80-96.

168 Joller N, Kuchroo VK. Tim-3, Lag-3, and TIGIT. Curr Top Microbiol Immunol 2017;410:127-56.

169 Wolf Y, Anderson AC, Kuchroo VK. Tim3 comes of age as an inhibitory receptor. Nat Rev Immunol 2020;20:173-85.

170 Daley D, Mani VR, Mohan N, et al. Dectin 1 activation on macrophages by galectin 9 promotes pancreatic carcinoma and peritumoral immune tolerance. Nat Med 2017;23:556-67.

171 Yau T, Dan X, Ng CCW, et al. Lectins with potential for anti-cancer therapy. Molecules 2015;20:3791-810.

172 Brown GD, Willment JA, Whitehead L. C-Type lectins in immunity and homeostasis. Nat Rev Immunol 2018;18:374-89.

173 Dambuza IM, Brown GD. C-Type lectins in immunity: recent developments. Curr Opin Immunol 2015;32:21-7.

174 Xia X, You M, Rao X-J, et al. Insect C-type lectins in innate immunity. Dev Comp Immunol 2018;83:70-9.

175 Nonaka M, Ma BY, Imaeda H, et al. Dendritic cell-specific intercellular adhesion molecule 3-grabbing non-integrin (DC-SIGN) recognizes a novel ligand, Mac-2-binding protein, characteristically expressed on human colorectal carcinomas. J Biol Chem 2011;286:22403-13.

176 van Gisbergen KPJM, Aarnoudse CA, Meijer GA, et al. Dendritic cells recognize tumor-specific glycosylation of carcinoembryonic antigen on colorectal cancer cells through dendritic cell-specific intercellular adhesion molecule-3-grabbing nonintegrin. Cancer Res 2005;65:5935-44.

177 Pagan JD, Kitaoka M, Anthony RM. Engineered Sialylation of Pathogenic Antibodies In Vivo Attenuates Autoimmune Disease. Cell 2018;172:564-77.

178 Chiba S, Ikushima H, Ueki $\mathrm{H}$, et al. Recognition of tumor cells by Dectin-1 orchestrates innate immune cells for anti-tumor responses. eLife 2014;3:e04177.

179 Vyas M, Reinartz S, Hoffmann N, et al. Soluble NKG2D ligands in the ovarian cancer microenvironment are associated with an adverse clinical outcome and decreased memory effector $T$ cells independent of NKG2D downregulation. Oncoimmunology 2017;6:e1339854.

180 Maccalli C, Giannarelli D, Chiarucci C, et al. Soluble NKG2D ligands are biomarkers associated with the clinical outcome to immune checkpoint blockade therapy of metastatic melanoma patients. Oncoimmunology 2017;6:e1323618.

181 Seifert L, Werba G, Tiwari S, et al. The necrosome promotes pancreatic oncogenesis via CXCL1 and Mincle-induced immune suppression. Nature 2016;532:245-9.

182 Sun L, LI C-W, Chung EM, et al. Targeting glycosylated PD-1 induces potent anti-tumor immunity. Cancer Res 2020:canres.3133.2019.

$183 \mathrm{Li} \mathrm{C-W}$, Lim S-O, Chung EM, et al. Eradication of triple-negative breast cancer cells by targeting glycosylated PD-L1.. Cancer Cell 2018;33:187-201.

184 Li C-W, Lim S-O, Xia W, et al. Glycosylation and stabilization of programmed death ligand-1 suppresses T-cell activity. Nat Commun 2016;7:12632.

185 Lee H-H, Wang Y-N, Xia W, et al. Removal of N-linked glycosylation enhances PD-L1 detection and predicts anti-PD-1/PD-L1 therapeutic efficacy. Cancer Cell 2019;36:168-78.

186 Höllsberg P, Scholz C, Anderson DE, et al. Expression of a hypoglycosylated form of CD86 (B7-2) on human T cells with altered binding properties to CD28 and CTLA-4. J Immunol 1997;159:4799-805.

187 Gross JA, St John T, Allison JP. The murine homologue of the T lymphocyte antigen CD28. Molecular cloning and cell surface expression. J Immunol 1990;144:3201-10.

188 Kalbasi A, Ribas A. Tumour-Intrinsic resistance to immune checkpoint blockade. Nat Rev Immunol 2020;20:25-39.

189 Yaguchi T, Goto Y, Kido K, et al. Immune suppression and resistance mediated by constitutive activation of Wnt/ $\beta$ catenin signaling in human melanoma cells. J Immunol 2012;189:2110-7.

190 Spranger S, Bao R, Gajewski TF. Melanoma-intrinsic $\beta$ catenin signalling prevents anti-tumour immunity. Nature 2015;523:231-5

191 Spranger S, Dai D, Horton B, et al. Tumor-Residing Batf3 dendritic cells are required for effector $T$ cell trafficking and adoptive $T$ cell therapy. Cancer Cell 2017;31:711-23.

192 Zhao F, Xiao C, Evans KS, et al. Paracrine Wnt5a- $\beta$-Catenin signaling triggers a metabolic program that drives dendritic cell Tolerization. Immunity 2018;48:147-60.

193 Sengupta PK, Bouchie MP, Nita-Lazar M, et al. Coordinate regulation of $\mathrm{N}$-glycosylation gene DPAGT1, canonical Wnt signaling and E-cadherin adhesion. J Cell Sci 2013;126:484-96.

194 Sun C, Mezzadra R, Schumacher TN. Regulation and function of the PD-L1 checkpoint. Immunity 2018;48:434-52.

195 Topper MJ, Vaz M, Chiappinelli KB, et al. Epigenetic therapy ties Myc depletion to reversing immune evasion and treating lung cancer. Cell 2017;171:1284-300.

196 Swamy M, Pathak S, Grzes KM, et al. Glucose and glutamine fuel protein O-GlcNAcylation to control T cell self-renewal and malignancy. Nat Immunol 2016;17:712-20. 